\title{
PORÓWNANIE OPINII WŚRÓD NIEPEŁNOSPRAWNYCH SPORTOWCÓW I STUDENTÓW UNIWERSYTETU SZCZECIŃSKIEGO NA TEMAT SPORTU INWALIDZKIEGO
}

\section{A COMPARISON OF OPINIONS ABOUT DISABLED SPORTS BETWEEN STUDENTS OF UNIVERSITY IN SZCZECIN AND DISABLED ATHLETES}

\author{
Studium Doktoranckie Wydziału Lekarskiego Pomorskiego Uniwersytetu Medycznego w Szczecinie \\ ul. Rybacka 1, 70-204 Szczecin \\ Kierownik: prof. dr hab. n. med. Maria Chosia \\ ${ }^{1}$ Samodzielna Pracownia Rehabilitacji Medycznej Pomorskiego Uniwersytetu Medycznego w Szczecinie \\ ul. Grudziądzka 31, 70-103 Szczecin \\ Kierownik: dr n. med. Iwona Rotter \\ ${ }^{2}$ Katedra i Zakład Zdrowia Publicznego Pomorskiego Uniwersytetu Medycznego w Szczecinie \\ ul. Żołnierska 48, 71-210 Szczecin \\ Kierownik: prof. dr hab. n. zdr. Beata Karakiewicz
}

\section{Summary}

Introduction: Sport among disabled people is becoming more and more popular. It is happening mostly due to the growing number of sports centres for the disabled, and the widespread popularization of this form of activity by organizations working for the benefit of disabled people. Also, the mass media play an important role in the process.

The aim of the study a comparison of the knowledge and opinions about disabled sports of physical education students and disabled athletes.

Methods: The research was conducted using two different questionnaires. One of them was given to students of Physical Education, the other to members of a disabled sports club, "Start". The questionnaires consisted of two sections: a personal profile, and 17 questions about disabled sports. 45 full-time students of Physical Education at the University of Szczecin: 30 (66.7\%) women and 15 (33.3\%) men. The average age of the group was 23.6 years. The second group, from the disabled sports club, consisted of 33 people, $18(54.5 \%)$ women and $15(45.5 \%)$ men; the average age of the participants was 28.6 years.

Results: Among the disabled people, 10 (30.3\%) people were unable to name any disabled athlete; among the group
\end{abstract}

of able-bodied students, there were $33(73.3 \%)$ people who were not able to do the same thing. According to students, disabled people do sports mainly for rehabilitation purposes (51.1\%). According to the disabled students' group, however, sport for disabled people means satisfaction and higher self-esteem (36.36\%). When it comes to the best source of information on the subject, television proved to be the best one among the media. The able-bodied students rated their knowledge of disabled sports as satisfactory (66.7\%), while only $6 \%$ of disabled students considered the knowledge of able-bodied people about disabled sports to be satisfactory.

Conclusions: 1 . The knowledge about disabled sports among students of physical education is superficial. The disabled also do not possess an extensive knowledge about disabled sports. 2. Opinion on the importance of sport in the lives of disabled people differ between the research groups. Able-bodied people see the role of sport mainly as a rehabilitation tool; disabled people, however, see it as an activity giving satisfaction and raising their self-esteem.

K e y w o r d s: disabled athletes - students - the disabled. 


\section{Streszczenie}

Wstęp: Uprawianie sportu przez niepełnosprawnych staje się zjawiskiem coraz bardziej powszechnym dzięki rosnącej liczbie ośrodków sportowych, szerszemu propagowaniu tej formy aktywności przez organizacje działające na rzecz inwalidów oraz środki masowego przekazu.

Celem pracy było porównanie wiedzy i opinii na temat sportu inwalidzkiego studentów kultury fizycznej i niepełnosprawnych sportowców.

Metody: Badania przeprowadzono metodą sondażu diagnostycznego, używając dwóch własnych kwestionariuszy ankiety, jeden dla studentów kultury fizycznej, drugi dla sportowców z Klubu Sportowego Inwalidów „Start”. Składały się one z metryczki i 17 pytań dotyczących sportu inwalidzkiego. Przebadano 45 studentów studiów stacjonarnych Wydziału Kultury Fizycznej i Promocji Zdrowia US: 30 (66,7\%) kobiet i 15 (33,3\%) mężczyzn. Średni wiek badanych wynosił 23,67 lat. Z klubu sportowego „Start” przebadano 33 osoby: $18(54,5 \%)$ kobiet i 15 (45,5\%) mężczyzn. Średni wiek badanych wynosił 28,57 lat.

Wyniki: Wśród osób niepełnosprawnych 10 (30,30\%) osób nie potrafiło wymienić nazwiska sportowca niepełnosprawnego; w grupie studentów takich osób było $33(73,30 \%)$. Zdaniem studentów uprawianie sportu to dla inwalidów przede wszystkim rehabilitacja $(51,11 \%)$, natomiast wg niepełnosprawnych to satysfakcja i podniesienie własnej samooceny $(36,36 \%)$. Spośród środków masowego przekazu telewizja okazała się najlepszym źródłem czerpania wiedzy w obu grupach. Zdaniem studentów, poziom posiadanej wiedzy odnośnie sportu niepełnosprawnych jest zadowalający $(66,7 \%)$; tylko $6 \%$ niepełnosprawnych uznało, że to prawda.

Wnioski: 1 . Wiedza studentów kultury fizycznej na temat sportu inwalidzkiego jest powierzchowna. Niepełnosprawni również nie posiadają dostatecznej ilości informacji o sporcie inwalidzkim. 2. Inna jest ocena roli sportu w życiu inwalidów w obu grupach badanych. Osoby zdrowe postrzegają rolę sportu głównie jako rehabilitację, zaś niepełnosprawni jako satysfakcję i podniesienie własnej samooceny.

$\mathrm{H}$ a s $\nmid$ a: sport niepełnosprawnych - studenci - inwalidzi.

\section{Wstęp}

Znaczenie ruchu i jego korzystnego wpływu na każdego człowieka jest znane od dawnych czasów. Ruch w pozytywny sposób wpływa na odporność organizmu, ogólny stan zdrowia oraz działa terapeutycznie na skutki niektórych chorób, niezależnie od wieku [1].

Aktywność sportowa jest doskonałą formą spędzania wolnego czasu oraz samorealizacji zarówno dla ludzi zdrowych, jak i niepełnosprawnych. Sport jest terminem trudnym do jednoznacznego zdefiniowania. Woleński twierdzi, że sport utożsamiany jest z kulturą fizyczną, sprowadza się do rozrywki oraz skierowany jest na sukces rywalizacji. Poza tym uważa się, że jest on także formą kontaktu z innymi ludźmi, zbliża ich do siebie, uczy zasad równości, jest szkołą przyjaźni, braterstwa i wspólnoty [2]. Człowiek niepełnosprawny przez sport może pokonać barierę zahamowań psychicznych i fizycznych, która go dzieli od ludzi zdrowych [3]. W 1880 r. po raz pierwszy ukazała się informacja w londyńskim „Times” o biegach publicznych, w których brało udział dwóch niepełnosprawnych. Wówczas zaczęto zauważać, że inwalidzi mogą uprawiać sport. Jednym z czynników, które miały wpływ na kształtowanie się sportu niepełnosprawnych była I wojna światowa. Jednak dopiero po II wojnie światowej rozwój aktywności sportowej wśród inwalidów nabrał rozmachu [4]. W okresie międzywojennym rozkwitała działalność organizacyjna, powstawały pierwsze kluby sportowe, zrzeszenia i federacje. Wówczas rozpoczęto także badania naukowe nad precyzowaniem wskazań i przeciwwskazań do rozpoczęcia uprawiania sportu przez inwalidów. Przełomowym momentem w rozwoju aktywności sportowej było wprowadzenie sportowych form rehabilitacji, gdyż wcześniej sport traktowano wyłącznie jako środek terapeutyczny $[4,5,6]$. W Polsce stosowano składowe treningu sportowego jako środka leczniczego w latach 60. XX w. Twórcami i propagatorami tego sposobu leczenia byli W. Dega i M. Weiss. Profesor Dega sformułował 3 podstawowe cechy, którymi sport niepełnosprawnych powinien się charakteryzować:

a) powinien być zgodny $z$ indywidualnym programem rehabilitacji medycznej,

b) powinien być bezpieczny,

c) powinien być powszechny, możliwy do uprawiania przez osoby z różnymi rodzajami schorzeń [7].

Minęły czasy, kiedy niepełnosprawnych uważano za osoby „gorsze” i nieprzystosowane do życia. Aktywność fizyczna podejmowana przez osoby zdrowe jest również dostępna dla niepełnosprawnych [3]. Osiągnięcie zwiększonej sprawności i wydolności fizycznej w sposób korzystny wpływa na psychikę oraz zachowanie społeczne, daje poczucie własnej wartości i ułatwia podjęcie pracy. Te wszystkie czynniki wpływają na integrację społeczną osób niepełnosprawnych w rodzinie, szkole, w pracy oraz na czynny udział w życiu społecznym [8].

Sport odgrywa bardzo ważną rolę w życiu każdego człowieka, bez wzglądu na stan zdrowia. Może być formą spędzania wolnego czasu, realizacją własnych marzeń, próbą przekraczania barier, rehabilitacją, a także dla niektórych zawodem. Współcześnie niepełnosprawni mogą i chcą być aktywni ruchowo [2]. Dzięki rosnącej liczbie ośrodków sportowych dla osób niepełnosprawnych oraz coraz lepiej wykwalifikowanej kadrze trenerskiej, możliwość uprawiania sportu systematycznie wzrasta zarówno dla osób niepełnosprawnych ruchowo, jak i umysłowo. Dostępność do różnych dyscyplin sportowych umożliwia każdemu inwalidzie realizacji własnych zainteresowań. Sport dla niepełnosprawnych powstał w wyniku wzorowania się na sporcie ludzi zdrowych, a jednocześnie spełnia 
kryteria kompleksowej rehabilitacji: fizycznej, psychologicznej i społecznej, a nawet zawodowej.

Jednym z najbardziej znanych ośrodków sportowych w Polsce jest Klub Sportowy Inwalidów „Start”, który powstał w 1983 r. z inicjatywy samych niepełnosprawnych. Od początku działalności klubu próbowano dotrzeć do jak największej liczby osób i zachęcić ich do uprawiania sportu. Celem jego działania jest organizowanie i rozwijanie powszechnej kultury fizycznej, sportu, rehabilitacji, turystyki i czynnego wypoczynku w środowisku inwalidów oraz członków ich rodzin. Przynależy do niego ok. 400 członków, wśród których część z nich uczęszcza na cykliczne zajęcia sportowe, natomiast pozostali uczestniczą w imprezach rekreacyjno-rehabilitacyjnych [9].

Dzięki szerszemu propagowaniu sportu niepełnosprawnych wzrasta akceptacja osób zdrowych dla niepełnosprawnych sportowców oraz zainteresowanie tym rodzajem sportu. Osobami, które w swojej pracy zawodowej mogą mieć kontakt ze sportem inwalidzkim są studenci kultury fizycznej, którzy w przyszłości mogą być trenerami sportowców inwalidów. Empatia, szacunek, chęć niesienia pomocy, zrozumienia, akceptacja to cechy, które powinni prezentować absolwenci tego kierunku studiów.

Celem pracy było porównanie wiedzy i opinii na temat sportu inwalidzkiego wśród osób niepełnosprawnych i studentów kultury fizycznej.

\section{Materiał i metody}

Badania przeprowadzono metodą sondażu diagnostycznego za pomocą dwóch własnych, różnych kwestionariuszy ankiety. Jeden z nich był przeznaczony dla studentów Wydziału Kultury Fizycznej i Promocji Zdrowia Uniwersytetu Szczecińskiego (WKFiPZ US), natomiast drugi dla osób niepełnosprawnych sportowców z Klubu Sportowego Inwalidów „Start”. Kwestionariusze składały się z dwóch części. Część pierwsza zawierała informacje o wieku, płci i miejscu zamieszkania. Część druga składała się z 17 pytań dotyczących sportu osób niepełnosprawnych. Pomimo tego, że obie ankiety były różne, to zawierały pytania, które można było porównać w obu grupach. Kwestionariuszami diagnozowano wiedzę i badano opinię studentów kultury fizycznej i niepełnosprawnych sportowców w zakresie tematyki sportu inwalidzkiego. Łącznie przebadano 45 studentów studiów stacjonarnych WKFiPZ US: $30(66,7 \%)$ kobiet i $15(33,3 \%)$ mężczyzn. Wiek studentów mieścił się w przedziale 22-28 lat, a jego średnia wyniosła 23,67 lat. Z klubu sportowego przebadano 33 osoby niepełnosprawne uprawiające sport: $18(54,5 \%)$ kobiet i $15(45,5 \%)$ mężczyzn. Wiek niepełnosprawnych mieścił się w przedziale 20-50 lat, a jego średnia wyniosła 28,57 lat. Uzyskane wyniki poddano analizie statystycznej, wykorzystując test niezależności $\chi^{2}$ z poprawką Yatesa, celem określenia zależności między badanymi grupami. Za istotny statystycznie przyjęto poziom $\mathrm{p} \leq 0,05$.

\section{Wyniki}

Zapytano respondentów obu badanych grup o wymienienie znanego nazwiska sportowca niepełnosprawnego (ryc. 1). Wśród badanych niepełnosprawnych 10 (30,30\%) osób nie znało żadnego nazwiska niepełnosprawnego sportowca; w grupie studentów było takich osób 33 (73,30\%). Stwierdzono istotną statystycznie zależność pomiędzy grupami a znajomością niepełnosprawnego sportowca $(\mathrm{p}<0,001)$.

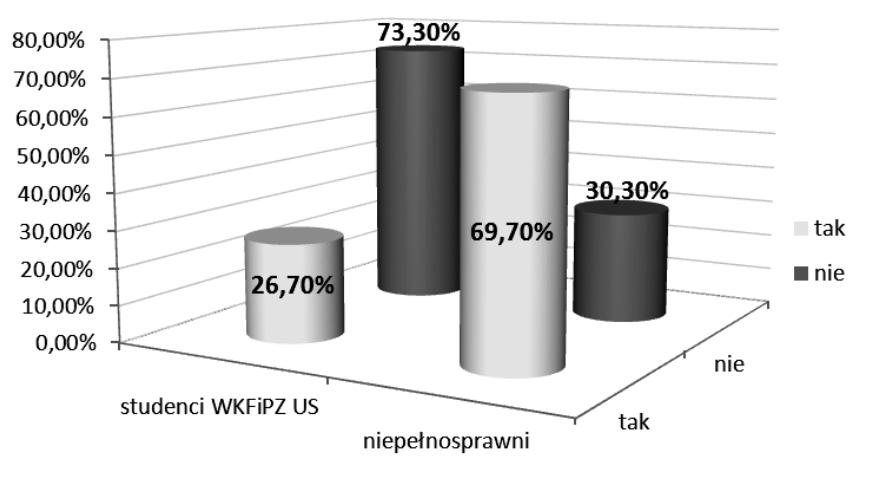

WKFiPZ - Wydział Kultury Fizycznej i Promocji Zdrowia Uniwersytetu Szczecińskiego.

Ryc. 1. Znajomość nazwiska znanego sportowca niepełnosprawnego

Następnie zapytano respondentów obu grup o rolę sportu w życiu niepełnosprawnych (tab. 1). Odpowiedzi miały zostać uszeregowane 1-3, gdzie 1 było najwyżej punktowane. Zdaniem studentów kultury fizycznej uprawianie sportu to dla inwalidów przede wszystkim rehabilitacja (I miejsce - 51,11\%), następnie kontakt z innymi ludźmi (II miejsce - 22,22\%) oraz satysfakcja i podniesienie własnej samooceny (III miejsce $-24,44 \%$ ). Natomiast wg niepełnosprawnych to przede wszystkim satysfakcja i podniesienie własnej samooceny (I miejsce $-36,36 \%$ ), następnie kontakty z innymi ludźmi (II miejsce $-27,27 \%$ ) oraz wypełnienie czasu wolnego (III miejsce $-27,27 \%$ ). Porównując uzyskane wyniki, można zauważyć różnice w udzielonych odpowiedziach w obu badanych grupach, ale nie stwierdzono istotności statystycznej $(p>0,05)$.

Zapytano respondentów obu grup o to, skąd można uzyskać informacje o istnieniu ośrodków sportowych. Najczęściej wymienianym źródłem czerpania wiedzy o sporcie dla niepełnosprawnych w obu grupach była telewizja. Następnie studenci WKFiPZ US 44,4\% korzystali w tej kwestii $\mathrm{z}$ internetu, a niepełnosprawni poza telewizją czerpali wiedzę odnośnie sportu inwalidzkiego od innych niepełnosprawnych $(18,20 \%)$.

Na pytanie, czy w Szczecinie funkcjonuje klub sportowy dla niepełnosprawnych $46,77 \%$ studentów odpowiedziało twierdząco. Niepełnosprawnym nie zadawano tego pytania, gdyż wszyscy wywodzili się z Klubu Sportowego „Start".

Zapytano studentów WKFiPZ US, czy kiedykolwiek uczestniczyli w zawodach sportowych osób niepełnosprawnych. Z badań wynika, że tylko 10 (22,22\%) osób z tej grupy 
T a b e l a 1. Porównanie opinii badanych osób na temat korzyści wynikających z uprawiania sportu

\begin{tabular}{|c|c|c|c|c|c|c|}
\hline \multirow{2}{*}{$\begin{array}{c}\text { Co Twoim zdaniem daje sport } \\
\text { osobie niepełnosprawnej? }\end{array}$} & \multicolumn{3}{|c|}{ Studenci kultury fizycznej } & \multicolumn{3}{|c|}{ Niepełnosprawni } \\
\hline & I & II & III & I & II & III \\
\hline Pomaga $\mathrm{w}$ rehabilitacji & $51,11 \%$ & $13,33 \%$ & $11,11 \%$ & $21,21 \%$ & $15,15 \%$ & $12,12 \%$ \\
\hline Zapewnia rozrywkę & $4,44 \%$ & $8,89 \%$ & $2,22 \%$ & $3,03 \%$ & $6,06 \%$ & $3,03 \%$ \\
\hline Wypełnia czas wolny & $0 \%$ & $4,44 \%$ & $4,44 \%$ & $3,03 \%$ & $18,18 \%$ & $27,27 \%$ \\
\hline Zapewnia kontakt z innymi ludźmi & $11,11 \%$ & $22,22 \%$ & $17,78 \%$ & $30,30 \%$ & $27,27 \%$ & $12,12 \%$ \\
\hline Daje możliwość osiągnięcia sukcesu & $2,22 \%$ & $13,33 \%$ & $22,22 \%$ & $0 \%$ & $15,15 \%$ & $12,12 \%$ \\
\hline Daje możliwość własnego rozwoju & $4,44 \%$ & $15,55 \%$ & $8,89 \%$ & $0 \%$ & $12,12 \%$ & $21,21 \%$ \\
\hline Daje satysfakcję i podnosi własną samoocenę & $22,22 \%$ & $20 \%$ & $24,44 \%$ & $36,36 \%$ & $6,06 \%$ & $3,03 \%$ \\
\hline Pozwala zapomnieć o niepełnosprawności & $4,44 \%$ & $2,22 \%$ & $8,89 \%$ & $6,06 \%$ & $0 \%$ & $9,09 \%$ \\
\hline
\end{tabular}

było na tego typu imprezie sportowej, natomiast 35 (77,78\%) osób nigdy w niej nie uczestniczyło. Spośród inwalidów $26(78,79 \%)$ osób uprawiających sport bierze udział jako kibice w zawodach sportowych. Jedynie 7 (21,21\%) osób przyznało, że nie uczestniczy w zawodach jako widz. Różnica jest istotna statystycznie pomiędzy studentami i inwalidami w zakresie odpowiedzi na pytanie o uczestnictwo w zawodach sportowych dla osób niepełnosprawnych $(\mathrm{p}<0,001)$.

Zapytano studentów WKFiPZ US, jak postrzegają osoby niepełnosprawne w społeczeństwie (tab. 2). Studenci w 93,33\% wykazują akceptację wobec niepełnosprawnych, traktując ich tak samo jak innych. Postawę obojętności zadeklarowało 6,67\% studentów. Badani niepełnosprawni w 54,54\% uważają, że są akceptowani przez osoby zdrowe, natomiast $45,46 \%$ jest zdania, że są traktowani przez zdrowych w sposób obojętny. Różnica uzyskana w odpowiedziach między obiema badanymi grupami jest istotna statystycznie $(\mathrm{p}<0,001)$.

T a b e 1 a 2. Nastawienie ludzi do niepelnosprawności

\begin{tabular}{lcc}
$\begin{array}{c}\text { Nastawienie } \\
\text { do niepełnosprawnych }\end{array}$ & Studenci & Niepełnosprawni \\
\hline Akceptacja & $93,33 \%$ & $54,54 \%$ \\
\hline Obojętność & $6,67 \%$ & $45,45 \%$ \\
\hline Brak akceptacji & $0 \%$ & $0 \%$ \\
\hline
\end{tabular}

Zapytano studentów, jak oceniliby stan posiadanej wiedzy na temat sportu niepełnosprawnych. Jako zadowalający swój poziom wiedzy odnośnie sportu inwalidzkiego oceniło $66,70 \%$ studentów kultury fizycznej, natomiast sportowcy w większości (94\%) stwierdzili, że osoby zdrowe nie posiadają zadawalającego poziomu wiedzy w tym zakresie. Różnica jest istotna statystycznie pomiędzy odpowiedziami udzielonymi przez obie badane grupy $(\mathrm{p}<0,001)$.

\section{Dyskusja}

W Polsce sport inwalidzki rozwija się bardzo dynamicznie, a świadomość społeczna i podejście do niepełnosprawności ulegają ciągłym zmianom [10]. Rehabilitacja przez sport pozwala szybciej pokonać kryzys psychiczny, a sport wyznacza nowe cele i dodaje wiary we własne możliwości. Na podstawie przeprowadzonych badań wśród uczestników Igrzysk Paraolimpijskich stwierdzono, że sport był dla nich w 94\% kontynuacją usprawniania leczniczego, a następnie podnosiła się ich sprawność ogólna i psychiczna. Dopiero na końcu stwierdzili, że sport wpłynął na akceptację swojego kalectwa i dodał pewności siebie [11]. Badania przeprowadzone przez Szeligę, co do korzyści płynących z uprawiania sportu, również dowodzą, że w sporcie dla inwalidów liczy się przede wszystkim kontynuacja rehabilitacji, potrzeba działania, aktywności ruchowej, zadowolenia z osiąganych wyników sportowych i możliwości kontaktów towarzyskich [12]. Badania własne przeprowadzone wśród studentów kultury fizycznej US i niepełnosprawnych z klubu „Start” na temat korzyści wynikających z uprawiania aktywności ruchowej dowiodły, że dla studentów sport inwalidzki to przede wszystkim rehabilitacja, a pozostałe wartości schodzą na dalszy plan. Powyższe wyniki badanych sportowców i studentów różnią się od siebie, ponieważ dla inwalidów z klubu „Start” sport to więcej niż tylko aktywność ruchowa zapobiegająca pogłębianiu się dysfunkcji. Dla nich to przede wszystkim satysfakcja i podniesienie własnej samooceny, możliwość kontaktu z innymi ludźmi oraz wypełnienie czasu wolnego.

Z badań prowadzonych wśród polskich sportowców niepełnosprawnych biorących udział w Letnich i Zimowych Igrzyskach Paraolimpijskich w latach 1972-1988 wynika, że 90\% osób miało poczucie alienacji ze środowiska ludzi zdrowych [13]. Głównymi przyczynami wyobcowania był brak informacji o sporcie i niepropagowanie go w środkach masowego przekazu, brak akceptacji ze strony ludzi zdrowych oraz brak integracji sportowców pełno- i niepełnosprawnych. Badani studenci WKFiPZ US najczęściej zdobywali informacje o ośrodkach sportowych, korzystając $\mathrm{z}$ internetu, natomiast żadna $\mathrm{z}$ badanych osób niepełnosprawnych w tej kwestii z tego źródła nie korzystała. Obecnie sport inwalidzki staje się coraz bardziej rozpowszechniany i nagłaśniany, lecz tych informacji jest wciąż za mało. Widzami na trybunach są przede wszystkim ludzie z najbliższego otoczenia inwalidów, natomiast studenci WKFiPZ US w większości przypadków nigdy nie byli na takiej imprezie sportowej. Tylko 30,3\% badanych studentów kultury fizycznej chodzi na zawody dla 
niepełnosprawnych. Niepełnosprawni badani w latach 1972-1988 oraz 45,5\% badanych z klubu „Start” skarżą się na brak akceptacji ze strony ludzi zdrowych, choć badani studenci w 93,3\% zadeklarowali, że akceptują osoby niepełnosprawne. Podobny wynik przedstawiła Lipińska-Lokś, która przeprowadziła badania dotyczące m.in. akceptacji niepełnosprawnych wśród uczniów szkoły publicznej i integracyjnej. Mniej więcej połowa uczniów z obu szkół chętnie spędza swój wolny czas z osobami pełno- i niepełnosprawnymi. Jednak pozostała część ankietowanych nadal pozostaje niechętna wobec kolegów niepełnosprawnych [14].

W literaturze zaobserwowano i odnotowano wiele widocznych korzyści, które wynikają z prowadzenia aktywnego stylu życia przez inwalidów znajdujących się w różnym przedziale wiekowym. Oprócz wszystkich wymienionych wcześniej zalet, sport zarówno u dzieci, jak i u dorosłych poprawia ogólny stan zdrowia, regulując poziom cukru we krwi, zapobiega powstawaniu cukrzycy oraz poprawia stan naczyń krwionośnych. Ma również wpływ na zdrowie psychiczne zapobiegając depresji i podnosząc pewność siebie [15, 16, 17, 18, 19, 20,21]. Wilson i Clayton w swoim artykule dowodzili, że badane dorosłe osoby niepełnosprawne uznały, że dzięki aktywności ruchowej opóźnieniu ulega proces starzenia, dłużej można zachować niezależność, zmniejsza się liczba urazów, a także możliwy jest wpływ na zmniejszenie bólu spowodowanego arthrosis [22]. Bouchard i Shephard udowodnili, że ćwiczenia mogą redukować zachorowalność na niektóre choroby oraz śmiertelność, ponieważ wpływają na organizm człowieka [23]. Wśród zachodzących zmian zauważono u sportowców poprawę wskaźnika masy ciała, obniżenie ciśnienia tętniczego krwi, poprawę profilu lipidowego oraz ochronę kości przed utratą gęstości. Dwyer $i$ wsp. zasugerowali, że wczesna aktywność fizyczna w sposób bezpośredni i pośredni poprawia stan zdrowia dorosłych i może mieć wpływ na późniejszą jakość życia tych osób [18, 24, 25].

W literaturze można znaleźć artykuły poruszające tematykę problemów psychicznych, fizycznych i społecznych oraz dotyczących szerzenia edukacji wśród niepełnosprawnych. Nie znaleziono publikacji dotyczących wiedzy społeczeństwa odnośnie sportu inwalidzkiego. Wskazane jest zatem pogłębienie badań dotyczących tej tematyki.

\section{Wnioski}

1. Studenci kultury fizycznej posiadają powierzchowną wiedzę na temat sportu dla niepełnosprawnych. Wiedza niepełnosprawnych sportowców jest większa, ale równie niezadowalająca.

2. Osoby zdrowe postrzegają rolę sportu przede wszystkim w wymiarze fizycznym (jako rehabilitację), a niepełnosprawni w psychologicznym (jako satysfakcję osobistą i wzrost samooceny).

\section{Piśmiennictwo}

1. Krajewska M., Grabowski H., Grabowski W.: Edukacja zdrowotna a styl życia uczniów gimnazjum. In: Promocja zdrowia w hierarchii wartości. NeuroCentrum, Lublin 2005, 92-96.

2. Woleński J.: Duch sportu. Agencja Wydawnicza, Kraków 1980.

3. Rucińska M.: Rehabilitacja poprzez sport. Post Med Klin Wojsk. 2008, (13) 2, 49.

4. Kujawa J., Janiszewski M.: Sport w rehabilitacji osób niepełnosprawnych jako forma wspomagania procesów regeneracji, adaptacji i kompensacji zaburzonych funkcji. Kwart Ortop. 2004, 1, 14-17.

5. Dromlewska D.: Sport niepełnosprawnych. Post Med Lot. 2004 (1), 145-146.

6. Kubicki W: Jak to było w przeszłości. Sport Niepełnosprawnych. 2004, 2, 18.

7. Zembaty A.: Kinezyterapia. Kasper, Kraków 2003, 168-169.

8. Milanowska K.: Znaczenie zwiększonej aktywności ruchowej osób niepełnosprawnych jako czynnika kompensującego ich sprawność psychofizyczną. In: Sport szansą życia niepełnosprawnych. Ed. J. Ślężyński J. Polskie Stowarzyszenie Osób Niepełnosprawnych, Kraków 1997, 28-30.

9. Niepełnosprawni. http://www.niepełnosprawni.info/ledge/x/9606 (18.09.2013).

10. McKnight J.: The careless socjety: Community and its counterfeits. Basic Books, New York 1995.

11. Kikolski W: Sport niepełnosprawnych - wyczyn czy rehabilitacja. Med Sport. 1999, 15 (12), 5-8.

12. Szeliga M.t.: Wysoka ocena osób niepełnosprawnych. Sport Niepełnosprawnych. 2004, 4, 29-32.

13. Sobiecka J.: Sport inwalidów - wyobcowany krąg ludzi? Post Rehab. 1999, 13, 3.

14. Lipińska-Lokś J.: Psychospołeczne funkcjonowanie uczniów niepełnosprawnych w klasach integracyjnych. In: Człowiek niepełnosprawny w różnych fazach życia. Ed. J. Bąbka. PZWL, Warszawa 2004, 81-91.

15. Murphy N.A., Carbone P.S.: Promoting the participation of children with disabilities in sports, recreation and physical activities. Pediatrics. 2008, 121 (5), 1057-1061.

16. Giannini M.J.: National initiative on physical fitness for children and youth with disabilities. In: Office on Disability Office of the Secretary. U.S. Department of Health and Human Services, 2004.

17. U.S. Department of Health and Human Services. National initiative on physical fitness for children and youth with disabilities 2004. http://www.hhs.gov/od/physicalfitness.html (12.02.2009).

18. Bar-or $O .:$ Health benefits of physical activity during childhood and adolescents. President Council on Physical Fitness and Sports Physical Activity and Fitness Research Digest. 1995, 2 (4), 1-8. http://www. fitness.gov/childhood.htm (12.02.2010).

19. Grange R.W., Call J.A.: Recommendations to define exercise prescription for Duchenne muscular dystrophy. Exerc Sport Sci Rev. 2007, 35 (1), 12-17.

20. Wilson P.E.: Exercise and sports for children who have disabilities. Phys Med Rehabil Clin N Am. 2012, 13 (4), 907-923.

21. Clark M.W.: The physically challenged athlete. Adolesc Med. 1998, 9 (3), 491-499.

22. Wilson P.E., Clayton G.H.: Sports and disability. Focused Rev. Suppl. 1, March 2010, S46-S54.

23. Bouchard C., Shephard R.J.: Physical activity, fitness and health. Champaign, IL: Human Kinetics Publishers; 1994.

24. Dweyer T., Magnussen C.G., Schmidt M.D.: Decine in physical fitness from childhood to adulthood associated with increased obesity and insulin resistance in adults. Diabetes Care. 2008, 32, 683-687.

25. Groff D.G., Lundberg N.R., Zabriskie R.B.: Influence of adapted sport on quality of life: Perceptions of athletes with cerebral palsy. Disabil Rehabil. 2009, 31 (4), 318-326. 